\title{
Breeding performance and disease profile of six peafowl species in captivity at Jallo breeding center, Lahore
}

\author{
Muhammad Tariq ${ }^{1}$, Nayab Saleem Butt ${ }^{1}$, Muhammad Mansha ${ }^{1 *}$ and \\ Munir Ahmad Bhinder ${ }^{2}$ \\ 1. Department of Zoology, Division of Science and Technology, University of Education, Lahore-Pakistan \\ 2. Department of human Genetics and Molecular Biology, University of Health Sciences, Lahore-Pakistan \\ *Corresponding author's email: $\underline{\text { dr.mansha@ue.edu.pk }}$
}

Citation

Muhammad Tariq, Nayab Saleem Butt, Muhammad Mansha, Munir Ahmad Bhinder. Breeding performance and disease profile of six peafowl species in captivity at Jallo breeding center, Lahore. Pure and Applied Biology. Vol. 8, Issue 1, pp312-320. http://dx.doi.org/10.19045/bspab.2018.700190

\begin{tabular}{llll}
\hline \hline Received: 14/08/2018 & Revised: 29/10/2018 & Accepted: 10/11/2018 & Online First: 19/11/2018
\end{tabular}

\section{Abstract}

Captive breeding is a process of raring the endangered species in man controlled environment like wild life parks, breeding centers and zoos. The present study was carried out to determine the reproductive and breeding performance of peafowls in captivity at Jallo Breeding Center, Lahore. Moreover, the study will also include the mortality causes of these birds. The data was collected from record registers and staff of captive breeding center of Jallo Park Lahore from (2009-2012) of 6 species of peafowls. Our findings revealed that average hatchability in six species was $33.5 \%$ in $2009,61.5 \%$ in $2010,54 \%$ in 2011 and $47.8 \%$ in 2012. The survival percentage in peafowls was $37.1 \%$ in $2009,94.3 \%$ in $2010,89.1 \%$ in 2011 and $81.6 \%$ in 2012 . Our findings indicated that most of the deaths in Peafowls were not investigated either due to putrefied bodies or missing reports (In Pavo cristatus 47\%, in Pavo cristatus mut.nigripennis 75\%, in Pavo cristus mut.alba $74 \%$, in Pavo muticus muticus 48\%, in Pavo muticus $63 \%$ and in Pavo cristatus mut.pied, $79 \%$ deaths were not documented). The average deaths recorded by the breeding center $(32.67 \%)$ were mainly caused by new castle disease virus (NDV), Enteritis, Hemorrhagic Enteritis, Hepatitis + NDV, Traumatic Gizzard, respiratory and heart failure. Taken together, the unhatchability of peafowl eggs and survival of chicks were quite low in captivity. Most of the deaths were not reported either due to putrefied bodies or missing reports.

Keywords: Captive breeding; Jallo breeding center; Peafowls; Reproductive performance; Mortality

\section{Introduction}

Captive breeding is a complex science that includes observation, response to animal behavior, design of surroundings, attention to nutrition, cleanliness and detailed records of the birds' genealogy and health. Captive breeding is a process of breeding endangered or rare species in human controlled environment such as Zoos, Breeding centers and Wildlife Parks. Captive breeding is useful method to produce animals on commercial scale. It is employed to develop sizeable, stable and healthy population to avoid extinction of endangered and rare 
species. It is in practice to reintroduce the rare species back in to natural environment/ habitats when their sufficient number is maintained in the captivity [1-3].

In Punjab (Pakistan), the first captive breeding center has been started at Jallo Wildlife Park Lahore in 1980 and it covers an area of 43 acres of the park. For the breeding of birds, pheasantries and cages are established here. Proper feeding, natural environment and water facilities are available to the birds. Prevention and cure of diseases within breeding centers and causes of death are recorded. Fencing of habitats is carried out and proper patrolling is started for the visitors' management. Wildlife Department has established seventeen different Wildlife Parks/ Wildlife Breeding centers and Zoos/ Safari Parks in Punjab due to successful breeding in Jallo Park. The total area covered by all these breeding centers is 3,168 acres [4].

In Pakistan, peafowls are mostly raised as pets in small or large aviaries and marketed in pet bird shops. They are famous for colorful and shining feathers. They are polygynous and possess two to three peahens in their harem $[5,6]$. In natural environment the size of Clutch is 8-9 eggs where as in captivity the peahen lays 8-20 eggs and the incubation period is about 28-30 days [7]. Different studies are being made to improve the breeding and reproductive performance of peafowls in terms cage size and mating sex ratios in Pakistan $[5,8,9]$. Many species of peafowl are endangered in Pakistan due to export/trade activities. It is reported that Alexandrine parakeet and peafowl are traded in large quantity in 1970. A large number of bird species found in Pakistan are endangered, threatened and vulnerable locally as well as globally. Among these species, White -tailed eagle, Peregrine falcon, Cheer pheasant, Great Indian bustard and Siberian white crane are included [10, $11]$.
Many captive breeding programs for rehabilitation of endangered species are launched and coordinated internationally through different organizations such as Species Survival Commission (SSC) and International Union for the Conservation of Nature (IUCN). Many conservation programs now use captive breeding to support endangered and threatened species [12]. Presently, it is estimated that thousands of species will require captive breeding to prevent their extinction over the next 200 years [5].

In the present study we find out the breeding performance, hatching success, mortality and its causes among six species of peafowl in captive breeding. It includes the assessment of birds' birth and mortality data of four years (from January 2009 to December 2012) collected from Jallo Wild life Breeding Centre.

\section{Materials and methods}

Recorded data of four years (2009-2012) for six species of peafowls namely Pavo cristatus, Pavo cristatus mut.nigripennis, Pavo cristus mut.alba, Pavo muticus muticus, Pavo muticus and Pavo cristatus mut.pied was collected from Jallo Park Breeding Center through official permission. The data was copied very carefully from the registers maintained by the staff of breeding center and was statistically analyzed for results. The collected data was mainly pertaining to captive breeding, breeding stocks, causes of mortality, procedure adopted for incubation and sanitation of eggs. Three types of reports such as "Eggs and Chicks Reports", "Mortality Reports" and "Stock \& Exchange Reports" (per season from 2009 to 2012) were collected from staff and record registers to analyze the data.

\section{Mortality reports}

The mortality reports mainly pertain to the causes of birds' death, investigation of the death or putrefaction of the dead bird. The available record showed that the carcasses of 
dead birds were sent for the post mortem to the Veterinary Research Institute (VRI), Lahore. The reports were subsequently analyzed and the data was compiled. Death in captive birds was caused by accidents (fighting among themselves), New castle disease virus (NDV), Coryza, liver intoxication, Enteritis, Hemorrhagic Enteritis, Colibacillosis, Heat stress, Chronic Respiratory Distress (CRD), Hepatitis, Nephritis, Lungs and Tracheal congestion, Feed Toxicity and snake bite. A sizeable number of deaths were either not investigated either due to putrefied body or missing reports. The "Eggs and Chicks Reports" and "Stock \& Exchange Reports" mainly described the collection of eggs, hatching of eggs, parental stock and chicks after hatching. The parental stock along with hatched chicks was kept in pheasantries till their sex was identified. In parental pheasantries, 3-4 females were kept with one male. Healthy breeder birds were kept in pheasantries to produce healthy viable eggs. During breeding season, eggs were collected daily from parental pheasantries. Date of egg laying and name of species were marked on every egg with led pencil. After being collection, the eggs were sanitized with fumigation.

\section{Results}

A summary of hatchability and survival rate of all the six species of peafowl from 20092012 is shown in (Table $1 \& 2$ ).

\section{Common peafowl (Pavo cristatus)}

Breeding Data on Common Peafowl are presented in (Table 3).The hatching percentage varied from $39 \%$ in 2009 to $64 \%$ in $2010,69 \%$ in 2011 and $55 \%$ in 2012. Overall hatching was $58 \%$.

Table 1. Hatchability of six species of peafowl (2009-2012) in captivity

\begin{tabular}{|c|c|c|c|c|}
\hline Yearwise Hatchability\% & $\mathbf{2 0 0 9}$ & $\mathbf{2 0 1 0}$ & $\mathbf{2 0 1 1}$ & $\mathbf{2 0 1 2}$ \\
\hline Pavo cristatus & 39 & 64 & 69 & 55 \\
\hline Pavo cristatus mut & 45 & 57 & 62 & 52 \\
\hline Pavo cristatus mut. alba & 32 & 63 & 56 & 38 \\
\hline Pavo muticus muticus & 24 & 53 & 43 & 0 \\
\hline Pavo muticus & 24 & 67 & 39 & 67 \\
\hline Pavo cristatus mut. pied & 37 & 65 & 55 & 75 \\
\hline Mean & 33.5 & 61.5 & 54 & 47.83 \\
\hline
\end{tabular}

Table 2. Survival rate of six species of peafowl (2009-2012) in captivity

\begin{tabular}{|c|c|c|c|c|}
\hline Yearwise Survival\% & $\mathbf{2 0 0 9}$ & $\mathbf{2 0 1 0}$ & $\mathbf{2 0 1 1}$ & $\mathbf{2 0 1 2}$ \\
\hline Pavo crisatus & 35 & 87 & 96 & 95 \\
\hline Pavo cristatus mut & 31 & 91 & 89 & 95 \\
\hline Pavo cristatus mut. alba & 30 & 97 & 85 & 100 \\
\hline Pavo muticus muticus & 37 & 100 & 83 & 0 \\
\hline Pavo muticus & 0 & 100 & 87 & 100 \\
\hline Pavo cristatus mut. pied & 90 & 91 & 95 & 100 \\
\hline Mean & 37.166667 & 94.333333 & 89.166667 & 81.666667 \\
\hline
\end{tabular}

Survival percentage also varied from $35 \%$ in 2009 to $87 \%$ in $2010,96 \%$ in 2011 and $95 \%$ in 2012, with an overall survival percentage of $81 \%$. Most of the dead birds $(46 \%)$ were found late and $7 \%$ deaths were not reported so in total $53 \%$ deaths were not investigated. Rest of the birds died of different diseases like NDV caused (25\%), Enteritis (11\%), Hemorrhagic Enteritis (3\%), Hepatitis + NDV (2\%), Traumatic Gizzard (2\%), and one 
percent by each of Enteritis + Nephritis, Coryza, Liver Intoxication and Hepatic Discoloration.
Black-shouldered peafowl (Pavo cristatus mut. nigripennis)

Breeding Data on Black-shouldered Peafowl are presented in (Table 4).

Table 3. Diseases of Common peafowl in captivity

\begin{tabular}{|c|c|c|c|c|c|c|c|c|c|c|c|c|}
\hline \multirow[b]{2}{*}{ Year } & \multicolumn{11}{|c|}{ Causes of mortality } & \multirow[b]{2}{*}{ Total } \\
\hline & & 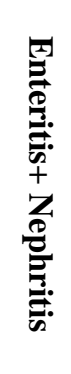 & 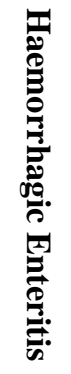 & 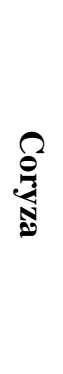 & 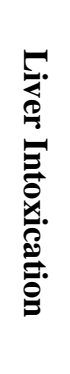 & 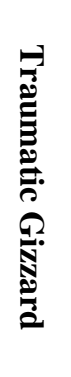 & 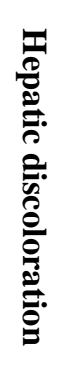 & 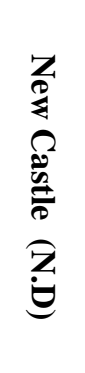 & 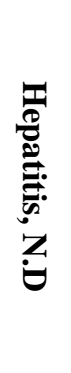 & 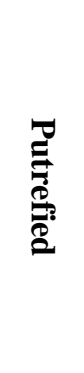 & 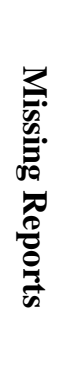 & \\
\hline 2009 & 1 & - & - & - & 1 & - & - & - & - & 6 & 2 & 10 \\
\hline 2010 & - & - & - & 1 & - & - & - & - & - & 8 & - & 9 \\
\hline 2011 & 1 & 1 & - & - & - & 1 & - & - & - & 9 & 1 & 13 \\
\hline 2012 & 11 & - & 4 & - & - & 1 & 1 & 30 & 2 & 31 & 5 & 85 \\
\hline Total & 13 & 1 & 4 & 1 & 1 & 2 & 1 & 30 & 2 & 54 & 8 & 117 \\
\hline Total \% & $11 \%$ & $1 \%$ & $3 \%$ & $1 \%$ & $1 \%$ & $2 \%$ & $1 \%$ & $25 \%$ & $2 \%$ & $46 \%$ & $7 \%$ & $100 \%$ \\
\hline
\end{tabular}

Table 4. Diseases of black-shouldered peafowl in captivity

\begin{tabular}{|c|c|c|c|c|c|c|c|c|c|c|c|c|c|c|c|}
\hline \multirow[b]{2}{*}{ Year } & \multicolumn{14}{|c|}{ Causes of mortality } & \multirow[b]{2}{*}{ Total } \\
\hline & 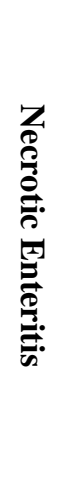 & 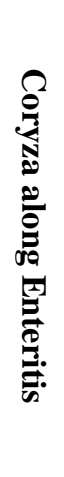 & $\tilde{\theta}$ & 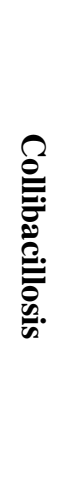 & 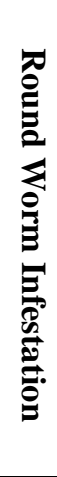 & 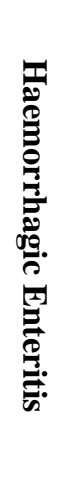 & 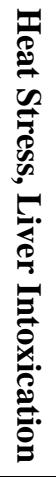 & 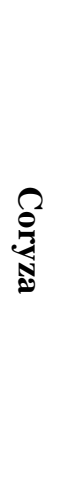 & 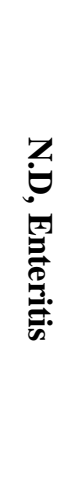 & 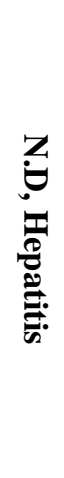 & 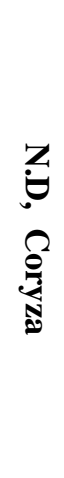 & : & 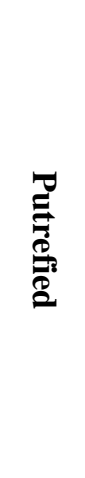 & 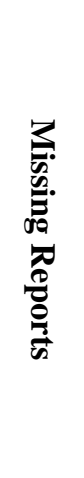 & \\
\hline 2009 & - & - & - & - & - & - & - & - & - & - & - & - & 9 & 5 & 14 \\
\hline 2010 & 1 & 2 & - & - & - & - & - & - & - & - & - & - & 25 & 4 & 32 \\
\hline 2011 & 1 & - & 1 & 1 & 1 & - & - & - & - & - & - & - & 8 & 3 & 15 \\
\hline 2012 & - & - & - & - & - & 1 & 1 & 1 & 10 & 2 & 2 & 1 & 17 & 4 & 39 \\
\hline Total & 2 & 2 & 1 & 1 & 1 & 1 & 1 & 1 & 10 & 2 & 2 & 1 & 59 & 16 & 100 \\
\hline $\begin{array}{c}\text { Total } \\
\%\end{array}$ & $2 \%$ & $2 \%$ & $1 \%$ & $1 \%$ & $1 \%$ & $1 \%$ & $1 \%$ & $1 \%$ & $10 \%$ & $2 \%$ & $2 \%$ & $1 \%$ & $59 \%$ & $16 \%$ & $100 \%$ \\
\hline
\end{tabular}

The hatching percentage varied from $45 \%$ in 2009 to $57 \%$ in $2010,62 \%$ in 2011 and $52 \%$ in 2012. Overall hatching was 55\%. Survival percentage also varied from $31 \%$ in 2009 to $91 \%$ in $2010,89 \%$ in 2011 and $95 \%$ in 2012 , with an overall survival percentage of $77 \%$.
Twelve different diseases caused death in Black shouldered peafowl. Each of the disease i.e., CRD, Colibacillosis, Round worm Infestation, Hemorrhagic Enteritis, Heat Stress + Liver Intoxication, Enteritis and Coryza caused $1 \%$ deaths in birds. Other 
causes of death included Necrotic Enteritis (2\%), Coryza along Enteritis (2\%), NDV + Hepatitis (2\%), NDV + Coryza (2\%). Of the rest NDV + Enteritis caused the most deaths (10\%). 16\% deaths were not reported. 59\% dead birds were found late and their deaths were not investigated due to their putrefied carcasses.

White peafowl (Pavo cristatus mut. alba) Breeding Data on White Peafowl are presented in (Table 5). The hatching percentage varied from $32 \%$ in 2009 to $63 \%$ in $2010,56 \%$ in 2011 and $38 \%$ in 2012 .
Overall hatching was $48 \%$. Survival percentage also varied from $30 \%$ in 2009 to $97 \%$ in $2010,85 \%$ in 2011 and $100 \%$ in 2012 , with an overall survival percentage of $79 \%$. In White Peafowl, 53\% dead bodies were not reported due to putrefied carcasses and $21 \%$ deaths were not investigated. Of the rest, Enteritis caused 5\% deaths and CRD, Coryza, Lungs Congestion, Coryza along Enteritis, Enteritis + Nephritis, Coryza + NDV + Feed Toxicity, Hemorrhagic Enteritis + Feed Toxicity each caused 3\% deaths.

Table 5. Diseases of white peafowl in captivity

\begin{tabular}{|c|c|c|c|c|c|c|c|c|c|c|c|}
\hline \multirow[b]{2}{*}{ Year } & \multicolumn{10}{|c|}{ Causes of mortality } & \multirow[b]{2}{*}{ Total } \\
\hline & $\tilde{\theta}$ & 国 & తి & 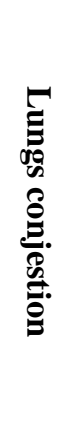 & 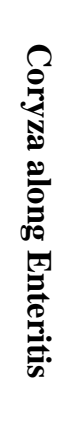 & 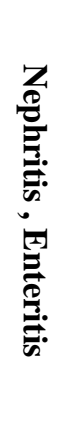 & 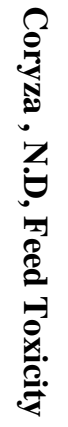 & 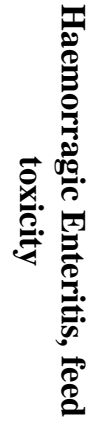 & 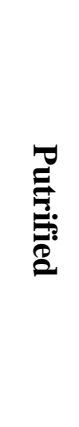 & 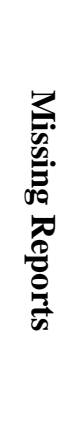 & \\
\hline 2009 & 1 & - & - & 1 & - & - & - & - & 3 & 6 & 11 \\
\hline 2010 & - & - & - & - & 1 & - & - & - & 9 & 2 & 12 \\
\hline 2011 & - & - & 1 & - & - & 1 & - & - & 8 & - & 10 \\
\hline 2012 & - & 2 & - & - & - & - & 1 & 1 & - & - & 4 \\
\hline Total & 1 & 2 & 1 & 1 & 1 & 1 & 1 & 1 & 20 & 8 & 37 \\
\hline Total \% & $3 \%$ & $5 \%$ & $3 \%$ & $3 \%$ & $3 \%$ & $3 \%$ & $3 \%$ & $3 \%$ & $53 \%$ & $21 \%$ & $100 \%$ \\
\hline
\end{tabular}

Java green peafowl (Pavo muticus muticus) Breeding Data on Java Green Peafowl are presented in (Table 6). The hatching percentage varied from $24 \%$ in 2009 to $53 \%$ in 2010, 43\% in 2011 and nil in 2012. Overall hatching was $34 \%$. Survival percentage varied from $37 \%$ in 2009 to $100 \%$ in 2010 , $83 \%$ in 2011 and nil in 2012, with an overall survival percentage of $75 \%$.

Deaths in Java Green Peafowl were due to NDV + Coryza + Enteritis (24\%), Coryza (8\%), Heat stress, Feed Toxicity, NDV and Accidents (4\%). Most of the deaths (36\%) were not reported due to putrefaction and $16 \%$ reports were missing.

\section{Emerald peafowl (Pavo muticus)}

Breeding Data on Emerald Peafowl are presented in (Table 7). The hatching percentage varied from $24 \%$ in 2009 to $67 \%$ in 2010, 39\% in 2011 and 67\% in 2012. Overall hatching was $40 \%$. Survival percentage also varied from $0 \%$ in 2009 to $100 \%$ in $2010,87 \%$ in 2011 and $100 \%$ in 2012 , with an overall survival percentage of 73\%. NDV + Enteritis caused $11 \%$ deaths and other causes of death included Enteritis + Nephritis (7\%), NDV (7\%), Lungs + Tracheal Congestion (4\%), NDV + Hepatitis $(4 \%)$, and NDV + Coryza + Feed Toxicity (4\%). A large number of dead birds (44\%) 
were not recorded as their carcasses were found putrefied and 19\% deaths were not reported due to missing reports; thus $63 \%$ deaths were not investigated.

Table 6. Diseases of java green peafowl in captivity

\begin{tabular}{|c|c|c|c|c|c|c|c|c|c|}
\hline \multirow[b]{2}{*}{ Year } & \multicolumn{8}{|c|}{ Causes of mortality } & \multirow[b]{2}{*}{ Total } \\
\hline & 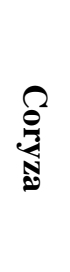 & 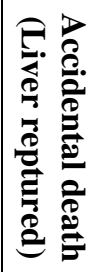 & 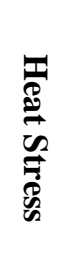 & 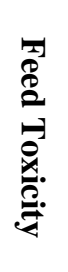 & 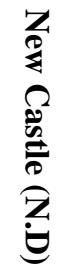 & 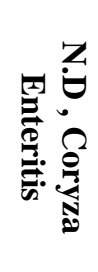 & 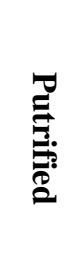 & 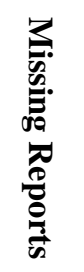 & \\
\hline 2009 & - & - & - & - & - & - & - & 2 & 2 \\
\hline 2010 & 1 & 1 & - & - & - & - & 3 & - & 5 \\
\hline 2011 & 1 & - & 1 & - & - & - & 1 & - & 3 \\
\hline 2012 & - & - & - & 1 & 1 & 6 & 5 & 2 & 15 \\
\hline Total & 2 & 1 & 1 & 1 & 1 & 6 & 9 & 4 & 25 \\
\hline Total \% & $8 \%$ & $4 \%$ & $4 \%$ & $4 \%$ & $4 \%$ & $24 \%$ & $36 \%$ & $16 \%$ & $100 \%$ \\
\hline
\end{tabular}

Table 7. Diseases of emerald peacock in captivity

\begin{tabular}{|c|c|c|c|c|c|c|c|c|c|}
\hline \multirow[b]{2}{*}{ Year } & \multicolumn{8}{|c|}{ Causes of mortality } & \multirow[b]{2}{*}{ Total } \\
\hline & 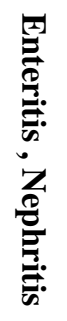 & 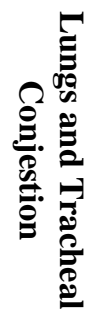 & 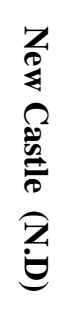 & 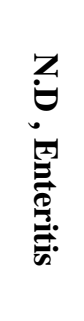 & 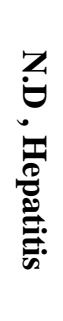 & 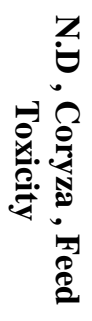 & 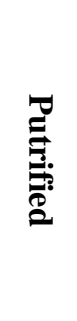 & 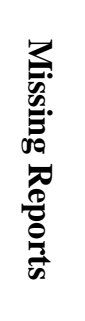 & \\
\hline 2009 & - & - & - & - & - & - & 3 & 1 & 4 \\
\hline 2010 & 1 & - & - & - & - & - & 1 & - & 2 \\
\hline 2011 & 1 & 1 & - & - & - & - & 2 & - & 4 \\
\hline 2012 & - & - & 2 & 3 & 1 & 1 & 6 & 4 & 17 \\
\hline Total & 2 & 1 & 2 & 3 & 1 & 1 & 12 & 5 & 27 \\
\hline Total \% & $7 \%$ & $4 \%$ & $7 \%$ & $11 \%$ & $4 \%$ & $4 \%$ & $44 \%$ & $19 \%$ & $100 \%$ \\
\hline
\end{tabular}

Pied peafowl (Pavo cristatus mut. pied)

Breeding Data of Pied Peafowl are presented in (Table 8). The hatching percentage varied from $37 \%$ in 2009 to $65 \%$ in $2010,55 \%$ in 2011 and $75 \%$ in 2012. Overall hatching was $54 \%$. Survival percentage also varied from $90 \%$ in 2009 to $91 \%$ in $2010,95 \%$ in 2011 and $100 \%$ in 2012, with an overall survival percentage of $94 \%$. NDV + Enteritis caused the most deaths (9\%). Colibacillosis, Hemorrhagic Enteritis, and NDV + Enteritis + Lungs Congestion, each of these diseases caused 4\% deaths. In Pied Peafowl, 79\% deaths were not investigated due to putrefied carcasses or some other reasons (Table 8).

\section{Discussion}

The present study pertains to four year breeding and reproductive performance (2009-2012) of peafowls in captivity at Jallo Breeding Center, Lahore. Peafowls being the spectacular birds are endangered species and are reared in the captivity all over the world [13].The management practices (feeding, housing, productive and reproductive performance) used for rearing the peafowls in captivity were different in different breeding 
centers in Pakistan [4]. In peafowls significant disparities were observed in hatching success. Overall number of hatched chicks in common peafowl and black shouldered peafowl (58\% and $77 \%$ ) were high than unhatched eggs ( $42 \%$ and $45 \%$ ) but survival rate of these chicks was substantially high $(81 \%$ and $77 \%)$ than the death rate $(19 \%$ and $23 \%$ ). Our data showed that there was significant increase in survival percentage of peafowl from 2009 to 2010 (57\%). Plenty of balanced diet, state of the art management techniques and absence of epidemics are likely the cause of better survival. It was also observed that death cause of almost $50 \%$ of birds was not clear in the present study. It is because of two reasons: first the deaths were not investigated due to putrefied/ missing dead bodies. Secondly, peafowl is a spectacular bird, human intervention like stealing/ missing of birds may be accounted for absence of clear death causes.

Table 8. Diseases of pied peafowl in captivity

\begin{tabular}{|c|c|c|c|c|c|c|c|}
\hline \multirow[b]{2}{*}{ Year } & \multicolumn{6}{|c|}{ Causes of Mortality } & \multirow[b]{2}{*}{ Total } \\
\hline & 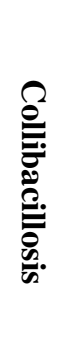 & 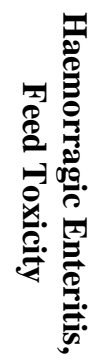 & 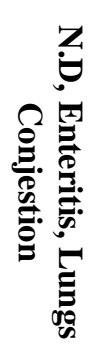 & 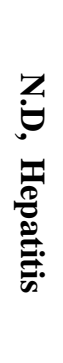 & 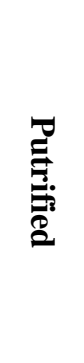 & 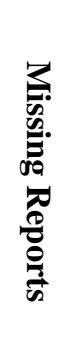 & \\
\hline 2009 & - & - & - & - & 1 & - & 1 \\
\hline 2010 & 1 & - & - & - & 7 & - & 8 \\
\hline 2011 & - & - & - & - & 2 & - & 2 \\
\hline 2012 & - & 1 & 1 & 2 & 8 & 1 & 13 \\
\hline Total & 1 & 1 & 1 & 2 & 18 & 1 & 24 \\
\hline Total \% & $4 \%$ & $4 \%$ & $4 \%$ & $9 \%$ & $75 \%$ & $4 \%$ & $100 \%$ \\
\hline
\end{tabular}

The overall percentage of chick hatching in Java green peafowl (Pavo muticus muticus), White peafowl (Pavo cristatus mut. alba) and Emerald peafowl (Pavo cristatus) was reasonably low $(34 \%, 48 \%$ and $40 \%)$ than unhatched eggs, $(66 \%, 52 \%$ and $60 \%)$ as shown in result section. In Pavo muticus muticus, the hatchability was recorded as 0 in 2012. The survival percentage of chicks in these species was high enough $(75 \%, 79 \%$ and $73 \%)$ than death rate $(25 \%, 21 \%$ and $27 \%$ ). It was observed that in captivity, the birds laid more eggs than natural environment [7]. The stress of captivity or plenty of good quality food might trigger the process of egg-laying in birds. From our findings it emerged that un-hatchability of eggs was a major problem associated with captive breeding. Hatchability is extremely sensitive process. The low hatchability in peafowls was supported by several reports which described that poor hatchability was linked with egg age [14] storage condition [15], age of flock [16, 17] system of husbandry and rearing technology [18], mating system [19], incubation relative humidity and eggs turning angle [20]. The poor hatchability in Jallo Breeding Center, as reflected by several investigations might be associated with early embryonic death, rotten egg, broken yolk, dead-in-shell chicks, prolonged pre-incubation storage, poor breeder nutrition, breeder age, contamination, incubator and hatcher malfunctions were the main problems associated with poor hatchability [21-26].

In present study, the investigated deaths in peafowls were caused by NDV, Coryza, 
Enteritis, Hepatitis + NDV, Traumatic Gizzard, Nephritis, Liver Intoxication and lung congestions recorded in the four years (2009-2012) data. Newcastle disease (ND) is a highly contagious and fatal disease affecting poultry and a wide range of wild birds worldwide $[27,28]$. The death toll of Peafowls in captivity at breeding center was further supported by [29] who reported that Peafowls raised in inadequate conditions, on poor quality feed and exposed to natural pathogens most frequently became victims of nutritional, viral, bacterial and parasitic diseases.

\section{Conclusion}

Majority of the peafowl species cannot successfully breed due to large number of diseases prevalent in the captivity. The hatching success is very low but survival rate is substantially high in captivity. Most of the deaths are not investigated either due to putrefied carcasses or missing reports. The unattended deaths or missing reports is alarming factor for the staff of captive breeding centers as it collapses their efforts regarding rehabilitation of endangered species. Keeping in view the reproductive performance in captivity, the staff of the breeding centers should be trained on regular basis regarding different aspects of rearing of captive animals.

\section{Authors' contributions}

Conceived and designed the experiments: $\mathrm{M}$ Tariq, Performed the experiments: NS Butt, Analyzed the data: M Mansha, Contributed materials/ analysis/ tools: MA Bhinder, Wrote the paper: M Mansha \& MT.

\section{Acknowledgements}

We are highly thankful to Mr. Riaz Ahmad, the incharge of Jallo wildlife breeding center for giving access to the data for the present study. We are obliged to Dr. Abrar Hussain, the Director Division of Science \& Technology, for facilitating the student for this project.

\section{References}

1. Cade TJ (1988). Using science and technology to re-establish species lost in nature. In: Biodiversity. Editors: Wilson EO. National Academy Press, Washington DC. pp 279-288.

2. Rahbeck C (1993). Captive breeding - A useful tool in the preservation of biodiversity? Biodivers \& Conserv 2: 426437.

3. Snyder NFR, Derrickson SR, Beissinger SR, Wiley JW, Smith TB, Toone WD \& Miller B (1996). Limitations of captive breeding in endangered species recovery. Conserv Biol 10: 338-348.

4. Ali Z, Bibi F, Mahel AQ, Firdous F, \& Saeed-U-Zamaan (2011). Captive breeding practices in Pakistan. J Animal Plant Sci 21: (2 Suppl) 368-371.

5. Allendorf FW \& Luikart G (2007). Conservation and the genetics of populations. Blackwell Publishing Oxford; (UK). 279-287 p.

6. Roberts TJ (1992). The birds of Pakistan. Nonpasseriformes. Karachi, Pakistan, Oxford University Press. Elite Publications limited pp 617-623.

7. Mushtaq-Ul-Hassan M, Ali Z, Arshad M, Mahmood S \& Mahmood-Ul-Hassan M (2012). Effects of mating sex ratios in Indian peafowl (Pavo cristatus) on production performance at Wildlife Research Institute, Faisalabad (Pakistan). IJVR 13: 143-146.

8. Anon (2002). Wildlife of the Punjab. Punjab Wildlife and Parks Department pp 13-25.

9. Mushtaq-Ul-Hassan M, Naz S, Abrar M, Mahmood S, Ali Z, Mahmood F \& Sarwar M (2013). Assessing the Effects of the Mating Sex Ratios on Reproductive Performance of Indian Peafowl, Pavo cristatus. Pakistan J Zool 45: 1623-1627.

10. Abrar M, Ahmad QA, Ali Z, Iqbal MA, Altaf S, Sagheer A, Hussain S, \& Khan L (2017). Effect of cage spacing on production, fertility and hatchability of eggs in Indian peafowl at wildlife breeding 
center (Gatwala), Faisalabad-Pakistan. $J$ Ent Zool Stud 5: 354-360.

11. ICBP (1977). Red Data Book-2. In: RED Data Book. Editor: Warren BKK. Vol. 2: Aves. $2^{\text {nd }}$ ed. Part 1. IUCN, Morges, 1978.

12. ICBP (1979). Red Data Book-2. In Warren, B.K.K. RED Data Book. Editor: Warren BKK. Vol. 2: Aves.2nd ed. Part 1. IUCN, Morges, 1980.

13. Khursheed A, Sial N, Malik S, \& Lashari M.L (2014). Parasitic infestation in Peafowl of Bahawalpur Zoo, Punjab, Pakistan. Standard Sci Res Essays 2: 401405.

14. Tarongoy JR, Eduave F \& Gemota EK (1990). Age as a factor of hatchability. SWUCA-J. Agric Res 5: 22-26.

15. Brah GS \& Sandhu JS (1989). Preincubation embryonic storage of guinea fowl eggs in cooling cabinet vs. room: Effect on hatchability components. Trop Agric (Trinidad and Tobago) 66: 265-268.

16. Roque L \& Soares MC (1994). Effects of eggshell quality and broiler breeder age on hatchability. Poult Sci 73: 1838-1845.

17. Buhr RJ (1995). Incubation relative humidity effects on allantoic fluid volume and hatchability. Poult Sci 74: 874-884.

18. Weis J (1991). Analysis of fertility, hatchability and egg quality indices in reproduction breeding of guinea fowls. Acta Zootechnica 47: 5-15.

19. Gebhardt-Henrich SG \& Mark HL (1991).The effect of switching males among caged females on egg production and hatchability in Japanese quail. Poult Sci 70: 1845-1847.

20. Permsak S (1996). Effect of water spraying and eggs turning angle to efficiency of duck hatchability Proceedings of the $34^{\text {th }}$ Kasetsart university annual conference, Bangkok (Thailand) 517: 22-26.
21. Deeming DC (1995). Factors affecting hatchability during commercial incubation of ostrich (Struthio camelus) eggs. $\mathrm{Br}$ Poult Sci 36: 51-65.

22. Van-Schalkwyk SJ, Cloete SWP, Brown CR \& Brand Z (2000). Hatching success of ostrich eggs in relation to setting, turning and angle of rotation. Br Poult Sci 41: 46-52.

23. Chabassi CS, Taddei S, Predari G, Galvani G, Ghidini F, Schiano E. \& Cavirani S (2004). Bacteriologic finding in ostrich (Struthiocamelus) eggs from farms with reproductive failure. Avian Dis 48: 716722.

24. Hassan SM, Siam AA, Mady MF, \& Cartwright AL (2004). Incubation temperature for ostrich (Struthio camelus) eggs. Poul Sci 83: 495-499.

25. Ipek, \& Hassan (2004). Effect of breeder age and breeding season on egg production and incubation farmed ostriches. Br Poult Sci 45: 643-647.

26. Malecki IA, Harbanczuk JO, Reed CE, \& Martin, GB (2005). The ostrich (Struthio camelus) blastoderm and embryo development following storage at various temperatures. Br Poult Sci 46: 642-660.

27. Miller PJ, Decanini E.L \& Afonso CL (2010). Newcastle disease: evolution of genotypes and the related diagnostic challenges. Infect Genet Evol 10: 26-35.

28. Dimitrov KM, Ramey AM, Qiu X, Bahl J \& Afonso CL (2016). Temporal, geographic and distribution of avian paramyxo virus 1 (Newcastle disease virus). Infect Genet Evol 39: 22-34.

29. Khan A, Yousaf A, Khan M Z, Siddique M, Gul ST \& Mahmood, F., (2009). Cutaneous form of pox infection among captive peafowl (Pavo cristatus) chicks. Avian Pathol 38: 65-70. 